\title{
USING ELEMENTAL CHEMOSTRATIGRAPHY ON MID-LATE FRASNIAN PLATFORM-TOP SUCCESSIONS FROM THE LENNARD SHELF OUTCROPS, CANNING BASIN, WESTERN AUSTRALIA
}

\author{
KENNETH RATCLIFFE \\ Chemostrat, Buttington Cross, Welshpool SY21 9BW, UK \\ e-mail:kenratcliffe@chemostrat.com \\ TED E. PLAYTON \\ Tengizchevroil, Atyrau 060011, Kazakhstan \\ PAUL MONTGOMERY \\ Chevron Upstream Europe, Chevron House, Aberdeen AB15 6XL, UK \\ DAVID WRAY, SAMUEL CAULFIELD-KERNEY \\ Department of Earth Sciences, University of Greenwich, Chatham Maritime, Kent ME4 9TB, UK \\ ERIC TOHVER \\ School of Earth and Environment, University of Western Australia, Perth, WA 6009, Australia \\ ROGER M. HOCKING, PETER W. HAINES \\ Geological Survey of Western Australia, East Perth, WA 6004, Australia \\ JOSEPH KIRSCHVINK \\ California Institute of Technology, Division of Geological and Planetary Sciences, 1200 E California Blvd., \\ Pasadena, California 91125 USA \\ AND \\ MAODU YAN \\ Institute for Tibetan Plateau Research, Chinese Academy of Sciences, Chaoyang District, Beijing 100101, People's \\ Republic of China
}

\begin{abstract}
High-resolution chronostratigraphic correlation using elemental chemostratigraphy in platform carbonates is typically difficult to achieve. Here, elemental chemostratigraphy is used to correlate between two platform-top, carbonate-dominated field sections from the narrow Lennard Shelf that existed on the NE margin of the Canning Basin, Western Australia, during the mid-late Frasnian. The correlation, constrained by magnetic polarity reversals and physical ground truthing, is based on recognition of distinctive cyclical "stacking patterns" defined by changes in concentrations of the trace element zirconium ( $\mathrm{Zr}$ ). $\mathrm{Zr}$ concentrations are controlled by the amount of the heavy mineral zircon in the sediments, which is derived from a terrigenous source and is diagenetically very stable. The stacking patterns in the lower part of the study sections display gradually upward-increasing values of $\mathrm{Zr}$ to a maximum, followed by an almost immediate fall to a minimum. In the upper part of the study interval, the cycles are more symmetrical, with both gradually increasing and decreasing portions. The point at which the change in $\mathrm{Zr}$ stacking pattern occurs in the two sections is synchronous and occurs in association with a supersequence maximum flooding surface. The correlation based on maximum and minimum $\mathrm{Zr}$ values throughout the two sections is demonstrated to be chronostratigraphic by comparison with correlations based upon paleomagnetism and physical ground truthing.

When element ratios commonly used as provenance and paleoclimate proxies are plotted, the variations between closely spaced samples are greater than any systematic variations throughout the study intervals. Therefore, no isochemical chemozones can be defined, implying that during deposition of the study intervals, there were no long-lived changes in sediment provenance or paleoclimate that the elemental chemistry can detect.

The work presented here shows that the standard approach of defining isochemical chemozones for chemostratigraphic correlation is not always appropriate. However, an approach using cyclical changes in elemental variables for chemostratigraphic correlation between two closely spaced sections is chronostratigraphically valid. The greater challenge is in application of the same approach to more widely spaced sections, potentially in different facies of a carbonate setting.
\end{abstract}

KEY wORDS: chemostratigraphy, mixed carbonate-siliciclastic sequences, Canning Basin, Lennard Shelf, attached platform

New Advances in Devonian Carbonates: Outcrop Analogs, Reservoirs, and Chronostratigraphy

DOI: http://dx.doi.org/10.2110/sepmsp.107.03

SEPM Special Publication No. 107, Copyright @ 2016

SEPM (Society for Sedimentary Geology), ISBN 978-1-56576-344-9, eISBN 978-1-56576-345-6, p. 319-331. 


\section{INTRODUCTION}

Chemostratigraphy, as used in this study, refers to the definition of stratigraphic units or surfaces using variations in whole-rock elemental concentrations. Typically, the aim of this chemostratigraphic approach is to identify elements and element ratios that change through time and that enable sediments of the same age to be correlated, or to differentiate sediments that are asynchronous. Published accounts of chemostratigraphy are largely from petroleum basins, mostly investigating fluvial siliciclastic systems and shale resource plays. In fluvial settings, the elemental data are typically used to recognize changes in paleoclimate (Pearce et al. 2005, Ratcliffe et al. 2010), changes in sedimentary facies, and changes in sediment provenance (Ehrenberg and Siring 1992, Armstrong-Altrin et al. 2004, Pe-Piper et al. 2008, Hildred et al. 2010, Wright et al. 2010, Ramkumar et al. 2011, Ratcliffe et al. 2015). In shale resource plays, the elemental data are commonly used to recognize terrigenous material influx and content (Algeo et al. 2004, Soua 2010, ver Straeten et al. 2011, Whalen et al. 2015) and as a proxy for bottom water conditions during deposition (Tribovillard et al. 2006, Rowe et al. 2012, Tinnin et al. 2013). These changes are then used to build a stratigraphic framework and provide stratigraphic correlations.

Published studies using elemental data on carbonate-dominated successions for stratigraphic correlation remain relatively uncommon. They often concentrate on elements associated with carbonate fraction (Pearce and Jarvis 1995, Jarvis et al. 2001, Wray and Gale 2006 , Mabrouk et al. 2007, Callonnec et al. 2014, Coimbra et al. 2015), rather than the major and trace element signatures associated with terrigenous contents (Stüben et al. 2005; Śliwiński et al. 2012; Davies et al. 2013, 2014; Craigie 2015). Work published on carbonate chemostratigraphy commonly notes that the cyclical variation in elemental compositions can be recognized on chemical logs (Mabrouk et al. 2007, Montgomery et al. 2011, Davies et al. 2013, Craigie 2015). Authors relate the cyclical variations to changes in the amount of terrigenous material in the carbonates (Montgomery et al. 2011, Davies et al. 2013) and to base-level fluctuations (Mabrouk et al. 2007, Davies et al. 2013, Craigie 2015). Cyclical fluctuations in terrigenous content that relate to base-level fluctuations in carbonate sediments are also commonly recognized from magnetic susceptibility studies (Ellwood et al. 2008, 2013; Da Silva et al. 2009; Whalen and Day 2010; Śliwiński et al. 2012) and in some mudrock studies (Sano et al. 2013).

The aim of this paper is to demonstrate that variations in elemental data associated with terrigenous content in a carbonate-dominated succession can be used to provide a chronostratigraphic correlation in carbonate settings. In order to achieve this goal, two chronostratigraphically well-constrained field sections from a carbonate platformtop setting were analyzed. The work also demonstrates that published approaches using elemental chemostratigraphy in siliciclastic settings, such as definition of isochemical chemozones, which reflect changing provenance or paleoclimate, do not provide meaningful results in the two field sections studied.

\section{STUDY MATERIAL}

Inorganic geochemical data were gathered from two field sections in the Canning Basin, Western Australia (Fig. 1). The sections are both in the Windjana Gorge area (Fig. 1) and contain sequences of mid-late Frasnian age, deposited in a platform-top setting, on a narrow $(\sim 5 \mathrm{~km})$ attached platform (Playford et al. 2009, Playton et al. 2016). The narrow shelf resulted in a terrestrial source always in close proximity to the carbonate factory on the platform top, yielding intricately commingled siliciclastic and carbonate litholo- gies (Fig. 2). The two studied sections, referred to as Windjana north A (WNA) and Windjana north B (WNB), are approximately 1 $\mathrm{km}$ apart and are $143 \mathrm{~m}$ and $171 \mathrm{~m}$ thick, respectively (Figs. 2, 3).

The work presented herein on the WNA and WNB sections is part of the Canning Basin Chronostratigraphy Project (CBCP), a multidisciplinary project integrating biostratigraphy, paleomagnetism, and stable isotope stratigraphy with field logging and sequence stratigraphy (Playton et al. 2016). The goal of CBCP, which includes numerous sections in addition to WNA and WNB, is to develop a chronostratigraphic correlation framework for the Middle to Upper Devonian carbonate system of the Lennard Shelf in Australia (Playton et al. 2016). Playton et al. (2016) demonstrate that the reefal system on the Lennard Shelf represents a supersequence spanning more than 25 Myr of time (second-order sequence of Sarg et al. 1999; after Playford et al. 2009; Playton and Kerans 2015a, 2015b; absolute age after Gradstein et al. 2012). When the two field sections of this paper are placed within the regional chronostratigraphic framework developed by the $\mathrm{CBCP}$, they are shown to contain a supersequence maximum flooding surface (MFS) that separates a supersequence transgressive systems tract (TST) from a supersequence highstand systems tract (HST) (Fig. 10 of Playton et al. 2016; Figs. 2, 3). The two study sections contain portions of only two composite sequences ( Fr5 and Fr6) (Fig. 3). The supersequence and component composite sequences are described in detail in Playton et al. (2016), where comparisons with sequences from previous research (George et al. 2009, Playford et al. 2009) are presented.

A physical tie between the two sections was provided by a ground truthing correlation done in the field during the generation of detailed field logs (Fig. 2), and refined stratigraphic correlation between the two sections was achieved using geomagnetic polarity reversals (Hansma et al. 2015, Hillbun et al. 2015, Playton et al. 2016). Regionally, additional stratigraphic data for the succession are provided from carbon isotope curves and conodont biostratigraphy. However, the primary marine isotopic signal that is needed to define chronostratigraphically significant excursions from carbon isotope data is compromised in the platform-top settings due to meteoric diagenetic overprint (Playton et al. 2016). Although conodont biostratigraphy is well established for Upper Devonian sequences in the Canning Basin (Klapper 2007), age-diagnostic Devonian conodonts are most common in slope to basin settings, and therefore platform-top sequences generally lack biostratigraphic control (Roelofs et al. 2015, Playton et al. 2016). Despite the limitations of carbon isotopes and biostratigraphy in platform-top settings, the high-confidence control from the magnetic reversals and ground truthing from the sections in Windjana Gorge (Figs. 2, 3) provide a well-constrained framework against which the elemental chemostratigraphy can be tested.

In the WNA section, the oldest sediments analyzed are a mixed siliciclastic-carbonate sequence deposited on the inner platform. Here, discrete, but discontinuous calcareous sandstone beds are common, separated by beds of mixed wackestone, packstone, and floatstone carbonate facies. These mixed lithologies pass upward into a series of stromatoporoid-dominated boundstones and floatstones deposited on reef-flat depositional environments (Playford et al. 2009). In WNB, a similar vertical change in facies is seen, but reef-flat facies remain interbedded with mixed-lithology inner- and outerplatform sediments, indicating that WNB was located slightly more landward than WNA (Fig. 3) (Playton et al. 2016).

During field logging, hand samples and core plugs were collected for analysis and were accurately placed within the field logs (Fig. 2). In total, 269 samples were analyzed from WNA, and 339 samples were analyzed from WNB. Although sample spacing was to some degree controlled by exposure, an average sample spacing of 


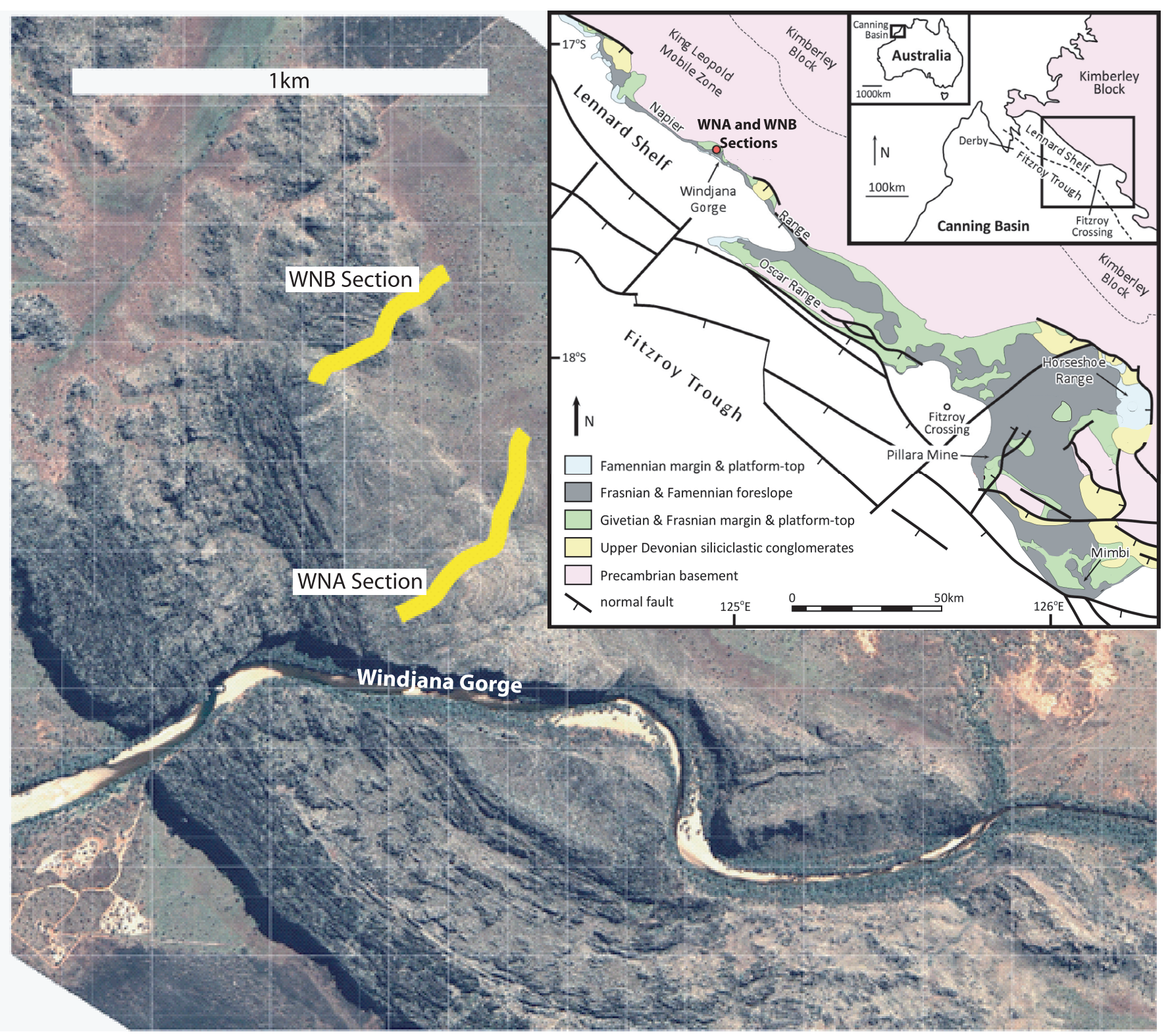

FIg. 1.-Location of WNA and WNB study sections. Top-right inset shows the location of the Canning Basin in NW Australia and the location of the larger inset base map. The base map is modified after Playford et al. (2009) and shows the position of the WNA and WNB sections. The satellite image shows the location of the two sections in detail, north of Windjana Gorge.

approximately $50 \mathrm{~cm}$ was achieved in each field section (Table 1 in Playton et al. 2016).

\section{DATA ACQUISITION}

Initially, all field samples were cleaned, and parts obviously affected by modern-day surficial weathering were removed. Approximately $10 \mathrm{~g}$ aliquots of the remaining sample were then ground to a fine powder in a ball mill. Although a $0.25 \mathrm{~g}$ aliquot of powder is used for analysis by inductively coupled plasma instruments, the $10 \mathrm{~g}$ homogenized powder sample provides better representation of the formation than $0.25 \mathrm{~g}$ of powder. In order to best carry out chemostratigraphic studies, data for a wide array of major and trace elements are required, and instrumentation that can detect and quantify these trace elements at very low abundances is needed for carbonate lithologies. For this study, the elemental data were acquired using inductively coupled plasma-optical emission spectrometry (ICP-OES) and inductively coupled plasma-mass spectrometry (ICP-MS), following a Li-metaborate fusion (Jarvis and Jarvis 1995). This methodology provides data for 10 major element oxides $\left(\mathrm{SiO}_{2}, \mathrm{TiO}_{2}, \mathrm{Al}_{2} \mathrm{O}_{3}, \mathrm{Fe}_{2} \mathrm{O}_{3}, \mathrm{MgO}, \mathrm{MnO}, \mathrm{CaO}\right.$, $\left.\mathrm{Na}_{2} \mathrm{O}, \mathrm{K}_{2} \mathrm{O}, \mathrm{P}_{2} \mathrm{O}_{5}\right), 25$ trace elements $(\mathrm{Ba}, \mathrm{Be}, \mathrm{Bi}, \mathrm{Co}, \mathrm{Cr}, \mathrm{Cs}, \mathrm{Cu}$, $\mathrm{Ga}, \mathrm{Hf}, \mathrm{Mo}, \mathrm{Nb}, \mathrm{Ni}, \mathrm{Pb}, \mathrm{Rb}, \mathrm{Sn}, \mathrm{Sr}, \mathrm{Ta}, \mathrm{Tl}, \mathrm{Th}, \mathrm{U}, \mathrm{V}, \mathrm{W}, \mathrm{Y}, \mathrm{Zn}, \mathrm{Zr}$ ), and 14 rare earth elements (La, Ce, Pr, Nd, Sm, Eu, Gd, Tb, Ho, Dy, Er, Tm, Yb, Lu). 

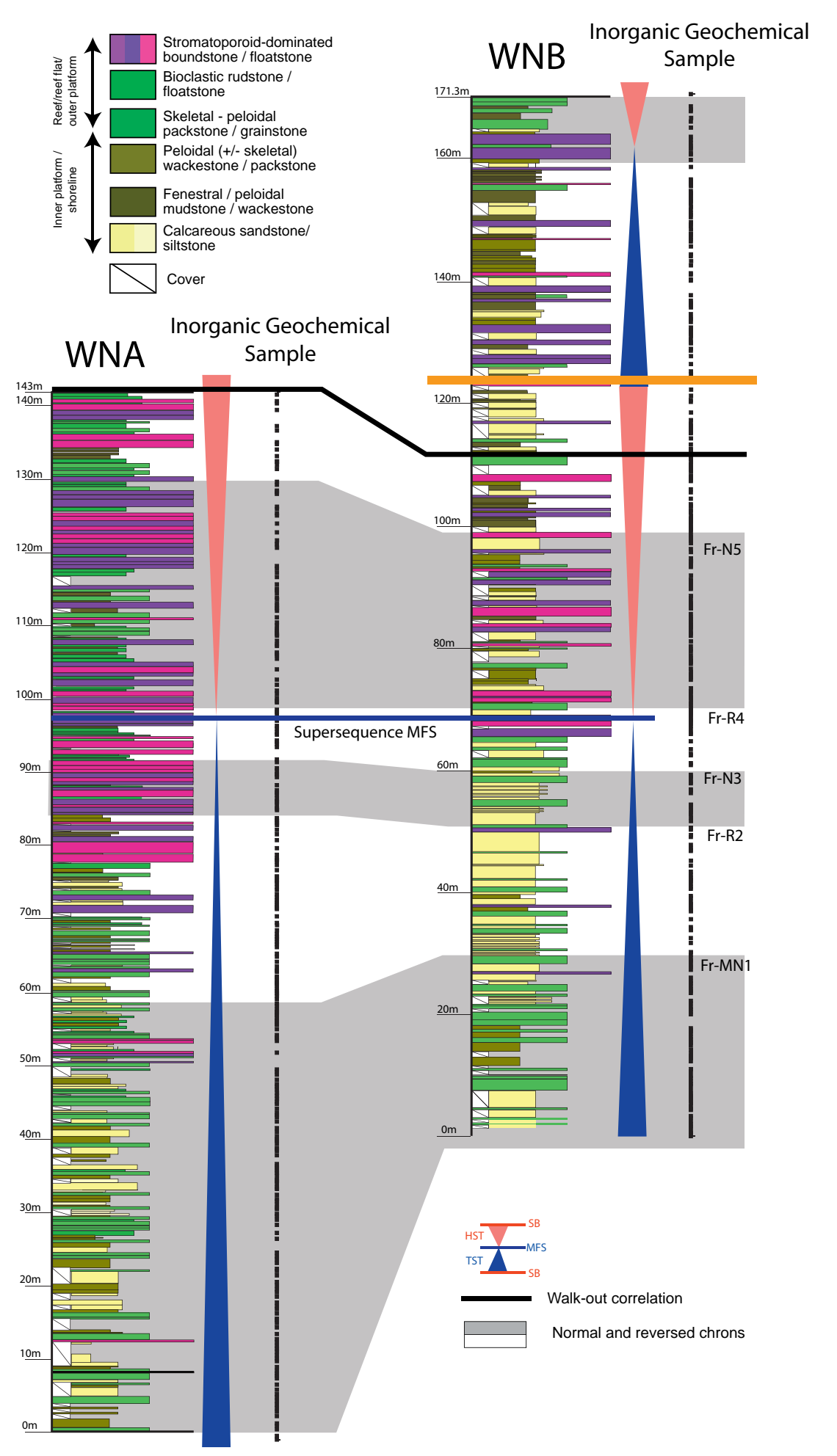

FIG. 2.-WNA and WNB measured sections. The black squares indicate the location of field samples analyzed by inductively coupled plasma (ICP) spectrometry for this paper. The gray shaded panels are normal polarity magnetic chrons (Hansma et al. 2015, Playton et al. 2016). A ground truthing correlation between the two sections, done in the field as a physical tie between the sections, is displayed. The supersequence MFS displayed is a surface that has been defined from the regional integrated chronostratigraphy and ground truthing from Windjana Gorge where margins and systems tracts can be observed in outcrop (Playton et al. 2016) across the Lennard Shelf carbonate system. 


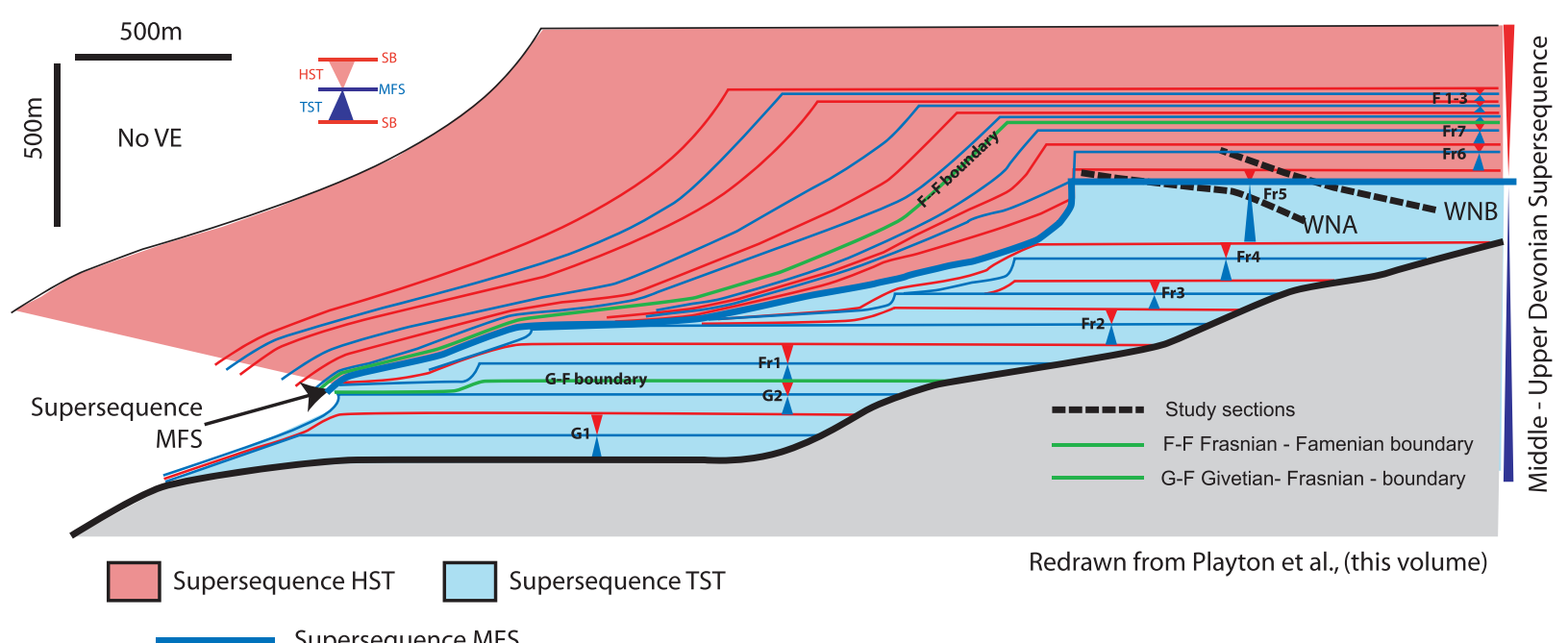

FIG. 3.- Hierarchical supersequence and composite sequence framework of the Lennard Shelf (redrawn from Playton et al. 2016). Bold dashed black lines are WNA and WNB measured sections true to actual surface topography and corrected for tilt. Supersequence TST and HST are blue and red shading, respectively, separated by a supersequence MFS. Composite sequence architecture is displayed by red and blue triangles that denote systems tracts, and red and blue lines denote sequence boundaries and maximum flooding surfaces, respectively. Gray shading indicates Precambrian and Paleozoic basement. Younger Famennian stratigraphy is not subdivided.

\section{APPLYING CHEMOSTRATIGRAPHIC METHODS TO WNA AND WNB}

Published accounts of elemental chemostratigraphy largely adopt a similar approach, where elemental data from lithologically similar intervals are used to define isochemical intervals of sediment termed chemostratigraphic packages (e.g., Ratcliffe et al. 2015 and references therein) or chemozones (e.g., Ramkumar 2015). A similar approach is explored here, and its limitations for this carbonate system study are discussed.

\section{Lithological Normalization and Separation}

Publications on siliciclastic chemostratigraphy advocate that different lithologies should be considered separately from one another when defining stratigraphic correlations (Pearce et al. 2005; Ratcliffe et al. 2006, 2015; Hildred et al. 2010). This, the authors argue, negates changes in elemental composition that reflect gross lithologica changes, thereby allowing more subtle variations in elemental chemistry that reflect provenance, climate, etc., to be recognized in lithologically similar facies. Furthermore, authors commonly argue for normalization of elements against $\mathrm{Al}_{2} \mathrm{O}_{3}$ to minimize the effect of changes in silt and clay contents of lithologies (Van der Weijden 2002; Pearce et al. 2005, 2010; Ratcliffe et al. 2015), although the validity of this approach has recently been questioned (Lowey 2015). These approaches proved problematic within the intricately mixed carbonate and siliciclastic lithologies of this study.

In a carbonate-dominated setting, $\mathrm{Al}_{2} \mathrm{O}_{3}$ and $\mathrm{SiO}_{2}$ concentrations are typically linked to terrigenous clay and quartz contents, whereas $\mathrm{CaO}$ reflects the amount of carbonate. In such a system, $\mathrm{SiO}_{2}$ and $\mathrm{Al}_{2} \mathrm{O}_{3}$ display a positive linear association with one another and negative association to $\mathrm{CaO}$; i.e., as carbonate increases, terrigenousderived content decreases. Figure 4A shows that while the majority of samples define a positive linear association (trend 1) on a $\mathrm{SiO}_{2}$ vs. $\mathrm{Al}_{2} \mathrm{O}_{3}$ cross-plot, two additional trends are noted. Trend 2 is formed by samples with high $\mathrm{SiO}_{2}$ values that show lesser associated increases in $\mathrm{Al}_{2} \mathrm{O}_{3}$ than trend 1 samples. Trend 3 is defined by samples with high $\mathrm{Al}_{2} \mathrm{O}_{3}: \mathrm{SiO}_{2}$ ratios relative to the samples that form trend 1. High $\mathrm{SiO}_{2}$ indicates higher quartz contents, whereas higher $\mathrm{Al}_{2} \mathrm{O}_{3}: \mathrm{SiO}_{2}$ values indicate higher clay contents. The samples that form trend 3 on Figure $4 \mathrm{~A}$ (high $\mathrm{Al}_{2} \mathrm{O}_{3}: \mathrm{SiO}_{2}$ ) are generally associated with stromatoporoid and microbial boundstones in the reef-flat facies, not, as would be expected, associated with the siliciclastic facies. High $\mathrm{Al}_{2} \mathrm{O}_{3}$ values, attributable only to fine-grained siliciclastic material (clay), are more common in the boundstone-associated facies than in the siliciclastic-dominated facies. This association of $\mathrm{Al}_{2} \mathrm{O}_{3}$ (clay) and boundstone facies could be due to reef-flat organism's preferentially binding sediment during their growth and/or sediment infilling of depositional cavities in reefal boundstone (Fig. 5A).

Samples that form trend 2, as expected, are associated with the sandstone beds at the base of WNA. However, there are also samples with high $\mathrm{SiO}_{2}$ and $\mathrm{SiO}_{2} / \mathrm{Al}_{2} \mathrm{O}_{3}$ values associated with reef-flat facies, where sandstone beds have not been recorded. These high $\mathrm{SiO}_{2}$, low $\mathrm{Al}_{2} \mathrm{O}_{3}$ samples in the reef-flat facies are associated with silicification and coarse quartz grains bound within the reefal sediments, both of which were observed in the field (Fig. 5B).

Therefore, while the mineralogical changes implied from elemental data in WNA and WNB can be readily explained geologically, the complex controls on lithologies in this mixed carbonate-siliciclastic setting negate the rationale of lithological sorting and $\mathrm{Al}_{2} \mathrm{O}_{3}$ normalization employed by siliciclastic chemostratigraphy studies.

The dolomitization recorded in the WNA and WNB sections adds another level of complexity to the interpretation of whole-rock inorganic geochemical data. Figure $4 \mathrm{~B}$ and $\mathrm{C}$ display $\mathrm{Al}_{2} \mathrm{O}_{3}$ vs. $\mathrm{CaO}$ and $\mathrm{SiO}_{2}$ vs. $\mathrm{CaO}$ cross-plots, respectively. On both binary plots, two negative trends are defined, both implying that as carbonate increases, quartz and clay decrease. As Figure 4D shows, there is a range of carbonates, from limestone with over $50 \% \mathrm{CaO}$ and $\mathrm{MgO}<2 \%$ to dolomites with $\mathrm{MgO}>15 \%$. The distributions of $\mathrm{SiO}_{2}, \mathrm{Al}_{2} \mathrm{O}_{3}, \mathrm{CaO}$, and $\mathrm{MgO}$ as proxies for quartz, clay, calcite, and dolomite within the sections are displayed in Figure 6. 

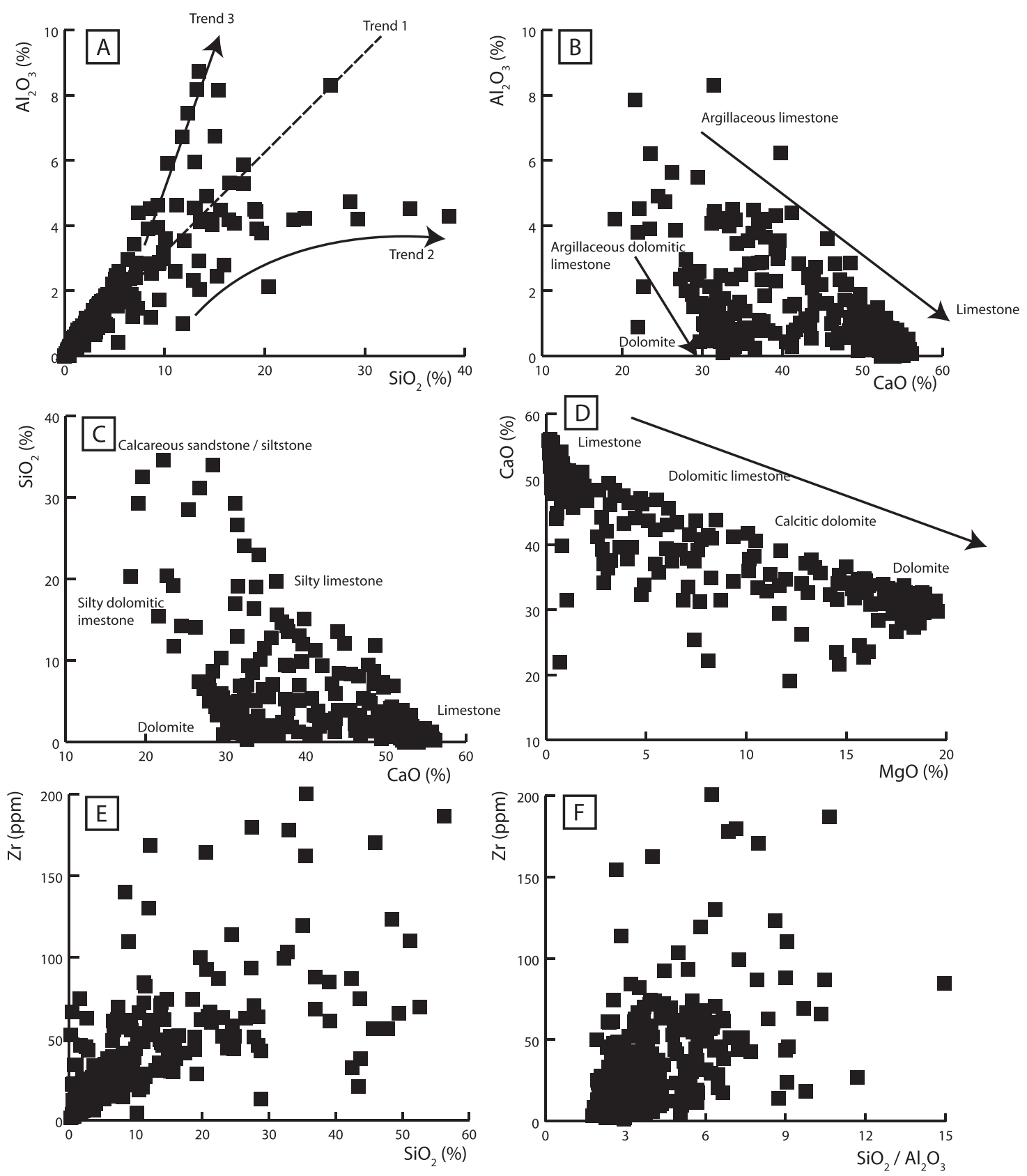

FIG. 4.-Selected elemental cross-plots used to help understand the lithological controls on the elemental data set.

\section{Definition of Isochemical Chemostratigraphic Packages}

Published siliciclastic chemostratigraphic papers define chemostratigraphic packages (e.g., Ratcliffe et al. 2010, 2015) or chemozones (e.g., Ramkumar et al. 2011, Craigie 2015) as the primary correlative features. Both chemostratigraphic packages and chemozones are defined as having distinctive element or element ratio values when compared to the rest of a section. Packages normally have a stepped base and top and therefore represent a discrete sequence of sediments that are "chemostratigraphically" distinctive and can be defined using graphical plots such as binary and ternary diagrams and using multivariate statistical methods such as principal components analysis. On Figure 6, a clear upward increase in $\mathrm{MgO}$ values at $57 \mathrm{~m}$ above the base of the WNA section shows a stepped change in concentration that can be used for chemostratigraphic package definition. However, the $\mathrm{MgO}$ values, as discussed already, are controlled by the amount of dolomitization, a feature that is unlikely to be of regional stratigraphic significance because dolomite bodies are not correlative over short distances in the field. Therefore, as discussed by many chemostratigraphic workers (e.g., Ratcliffe et al. 2010, 2015), if package definition is to be stratigraphically useful, it needs to be based on element ratios that are related to changes in parameters that are linked to stratigraphy. 

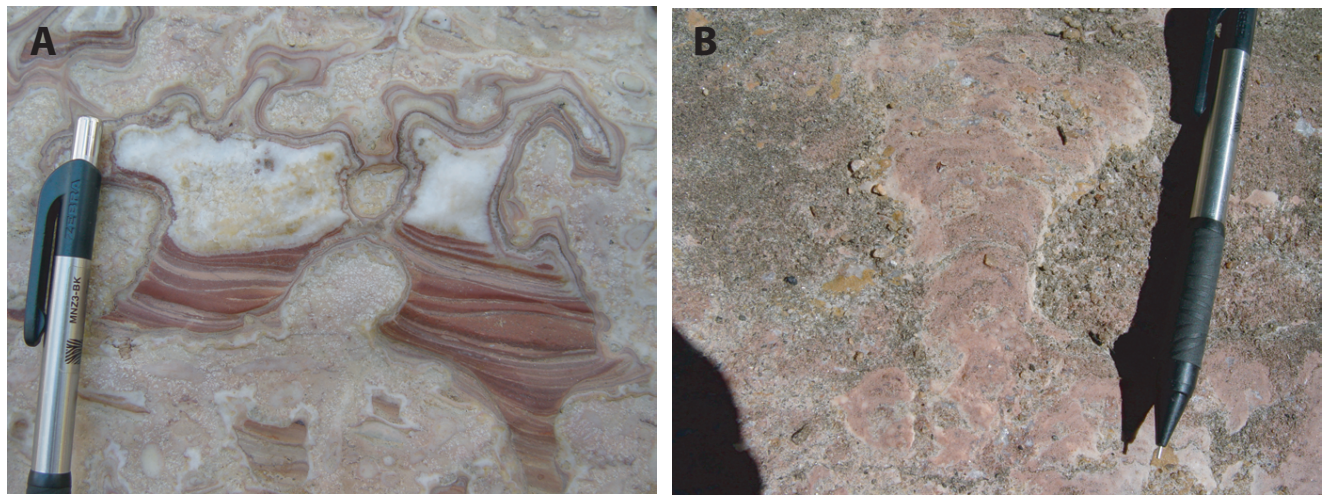

FIG. 5.-Field photographs showing examples of intimate association of siliciclastic sediment and reef-forming organisms. A) Silt-sized quartz and carbonate micropeloids filling reef cavity. B) Sand-size quartz, surrounding and encrusted into digitate stromatolitic growth in the reef flat.

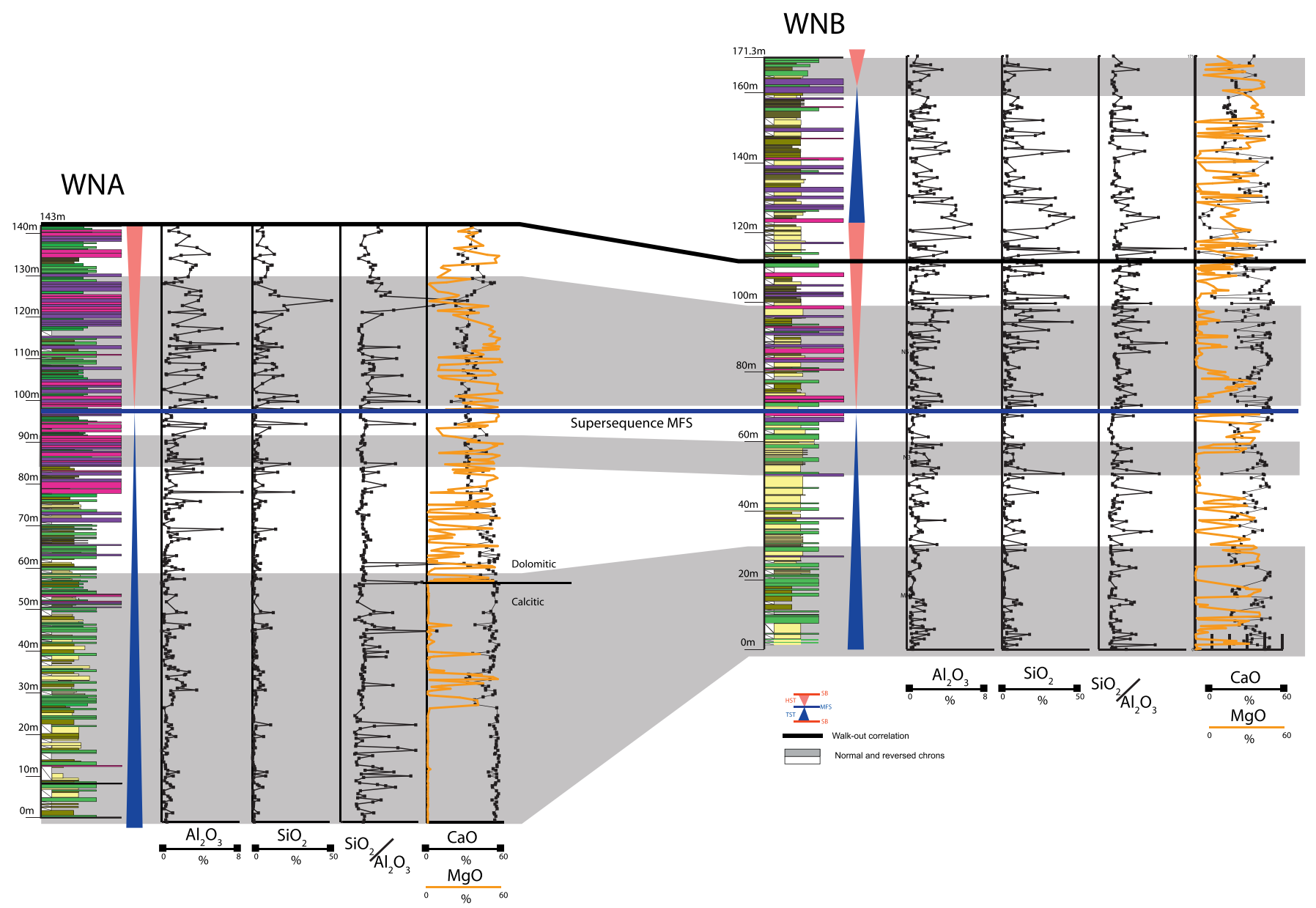

FIG. 6. $-\mathrm{SiO}_{2}, \mathrm{Al}_{2} \mathrm{O}_{3}, \mathrm{CaO}$, and $\mathrm{MgO}$ plotted as chemical logs to display changes in lithology through the sections. Marked change in $\mathrm{MgO}$ at $57 \mathrm{~m}$ in WNA is highlighted; see text for discussion. Refer to Figure 2 for facies codes in measured sections. 


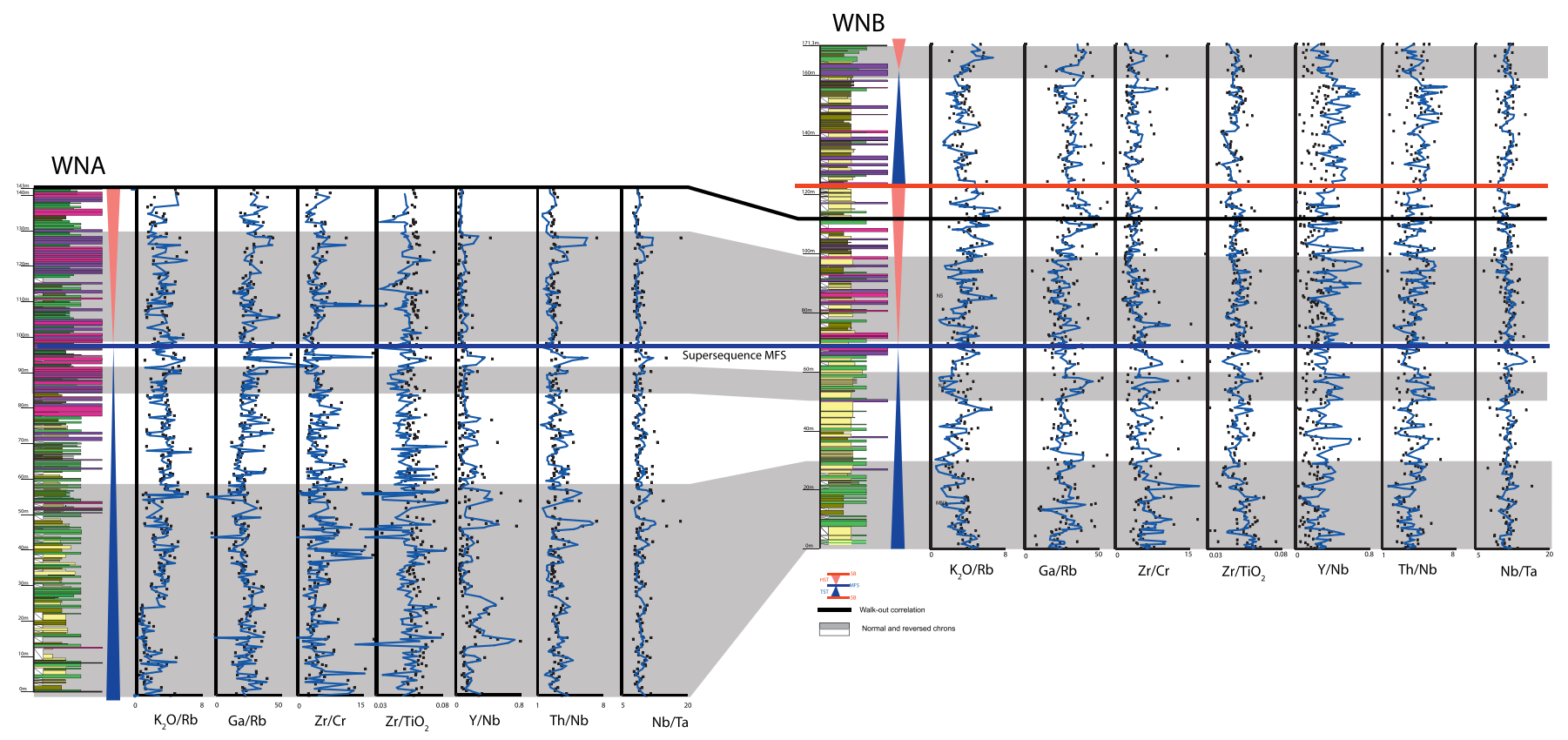

FIG. 7.- Selected element ratios plotted as chemical logs. The ratios chosen are typically used in siliciclastic chemostratigraphy studies to model changes in feldspar content $\left(\mathrm{K}_{2} \mathrm{O} / \mathrm{Rb}\right)$, paleoclimate $(\mathrm{Ga} / \mathrm{Rb})$, and provenance $\left(\mathrm{Zr} / \mathrm{Cr}, \mathrm{Zr} / \mathrm{TiO}_{2}, \mathrm{Y}_{/} \mathrm{TiO}_{2}, \mathrm{Th} / \mathrm{Nb}\right.$, and $\left.\mathrm{Nb} / \mathrm{Ta}\right)$. In each case, black squares represent the unprocessed data, and the blue line is a moving average with $n=3$. Refer to Figure 2 for facies key.

The approach of defining stratigraphically significant isochemical packages has been tried in WNA and WNB, using elemental ratios interpreted in the literature to be paleoclimate driven $(\mathrm{Ga} / \mathrm{Rb}$; Ratcliffe et al. 2010), feldspar content driven $\left(\mathrm{K}_{2} \mathrm{O} / \mathrm{Rb}\right.$; Ratcliffe et al. 2006, Wright et al. 2010), and provenance driven $(\mathrm{Zr} / \mathrm{Cr}-\mathrm{Ratcliffe}$ et al. 2007; $\mathrm{Zr} / \mathrm{TiO}_{2}$ - Pearce et al. 2005, Stüben et al. 2005). The chemical logs are displayed on Figure 7, where it is apparent that the amount of variation between closely spaced samples is typically large when compared to the overall variation in the entire section, resulting in chemical $\log$ s that lack systematic variation. Even when a moving average is applied in an attempt to negate small-scale chemical fluctuations, there are no obvious systematic trends in the chemical $\operatorname{logs}$ on Figure 7 . The types of stepped changes described in many siliciclastic chemostratigraphy papers are not apparent in WNA and WNB, therefore making definition of isochemical chemostratigraphic packages problematic.

\section{CHEMOSTRATIGRAPHIC CORRELATION OF WNA AND WNB}

When $\mathrm{Zr}$ is plotted as chemical logs for WNA and WNB, cyclical variations are apparent (Fig. 8). Furthermore, the shape of the cycles changes through time within a section. $\mathrm{Zr}$ concentrations best display the cyclical variations in the two study intervals of this paper (Fig. 8). $\mathrm{Zr}$ is commonly used as a proxy for the heavy mineral zircon in both siliciclastic and carbonate studies (Pearce et al. 2005, Stüben et al. 2005, Ratcliffe et al. 2012, Sano et al. 2013, Craigie 2015). The only source of zircon is a terrigenous one; i.e., it cannot be derived by interactions with seawater. Zircon is also mechanically and chemically stable (Hubert 1962), remaining unaffected by early or late burial diagenesis (Morton and Hallsworth 2007); hence, it is an effective proxy for terrigenous input. Therefore, $\mathrm{Zr}$ concentrations in carbonate sediments will reflect the amount of zircon deposited, which in turn will relate to the amount of terrigenous material in the carbonate.
In the oldest parts of the studied intervals, each $\mathrm{Zr}$ cycle displays a gradual upward increase to a maximum, followed by a sharp decrease (cycles labeled 1a-6a on Fig. 8), giving a clear sawtooth $\mathrm{Zr}$ stacking pattern in the lower parts of the study intervals. Each one of these upward-increasing $\mathrm{Zr}$ sequences is approximately 10 to $15 \mathrm{~m}$ thick. At $82 \mathrm{~m}$ above the base of the WNA section, a maximum in $\mathrm{Zr}$ values (7a) is followed by a 10 -m-thick sequence in which the $\mathrm{Zr}$ values gradually decrease upward (labeled $7 \mathrm{~b}$ in Fig. 8). This paired association of upward increase (7a-10a) and upward decrease (7b$10 \mathrm{~b}$ ) is continued in the upper parts of the studied intervals, reflecting a marked change in the Zr stacking pattern at $82 \mathrm{~m}$ in WNA (Fig. 8).

In $\mathrm{WNB}$, the $\mathrm{Zr}$ stacking pattern exhibits a sawtooth pattern of upward gradual increases to a maximum, and then a sharp fall until 50 $\mathrm{m}$ above the base of the section. Above $50 \mathrm{~m}$ in $\mathrm{WNB}$, the patterns are more symmetrical, with upward-increasing sections followed by upward-decreasing patterns (Fig. 8). The first significant upwarddecreasing $\mathrm{Zr}$ trend $(7 \mathrm{a}-7 \mathrm{~b})$ occurs at $50 \mathrm{~m}$ in WNB and $82 \mathrm{~m}$ in WNA, allowing this signature to be correlated between the two sections. The change in character in WNA is within a reef-top sequence of boundstones, whereas in WNB, it is within a siliciclasticcarbonate sequence of inner- to outer-platform deposits, suggesting the change in $\mathrm{Zr}$ stacking pattern is independent of facies. On Figure 8 , the correlation line between $82 \mathrm{~m}$ in WNA and $50 \mathrm{~m}$ in WNB is immediately below the top of the Fr-R2 Chron (for discussion of paleomagnetic chron nomenclature, see Playton et al. 2016), indicating that the change in $\mathrm{Zr}$ stacking patterns is synchronous in the two sections. Figure 8 further demonstrates that above and below this change, maxima and minima in the $\mathrm{Zr}$-stacking patterns match the paleomagnetic, physical, and supersequence MFS correlation. This suggests that the $\mathrm{Zr}$-based stacking pattern correlation is chronostratigraphic between WNA and WNB.

The cycles used for the correlation between WNA and WNB are decimeter-scale features (Fig. 8). However, cyclicity is also apparent on the meter and hundred-meter scales. The values of $\mathrm{Zr}$ at each 


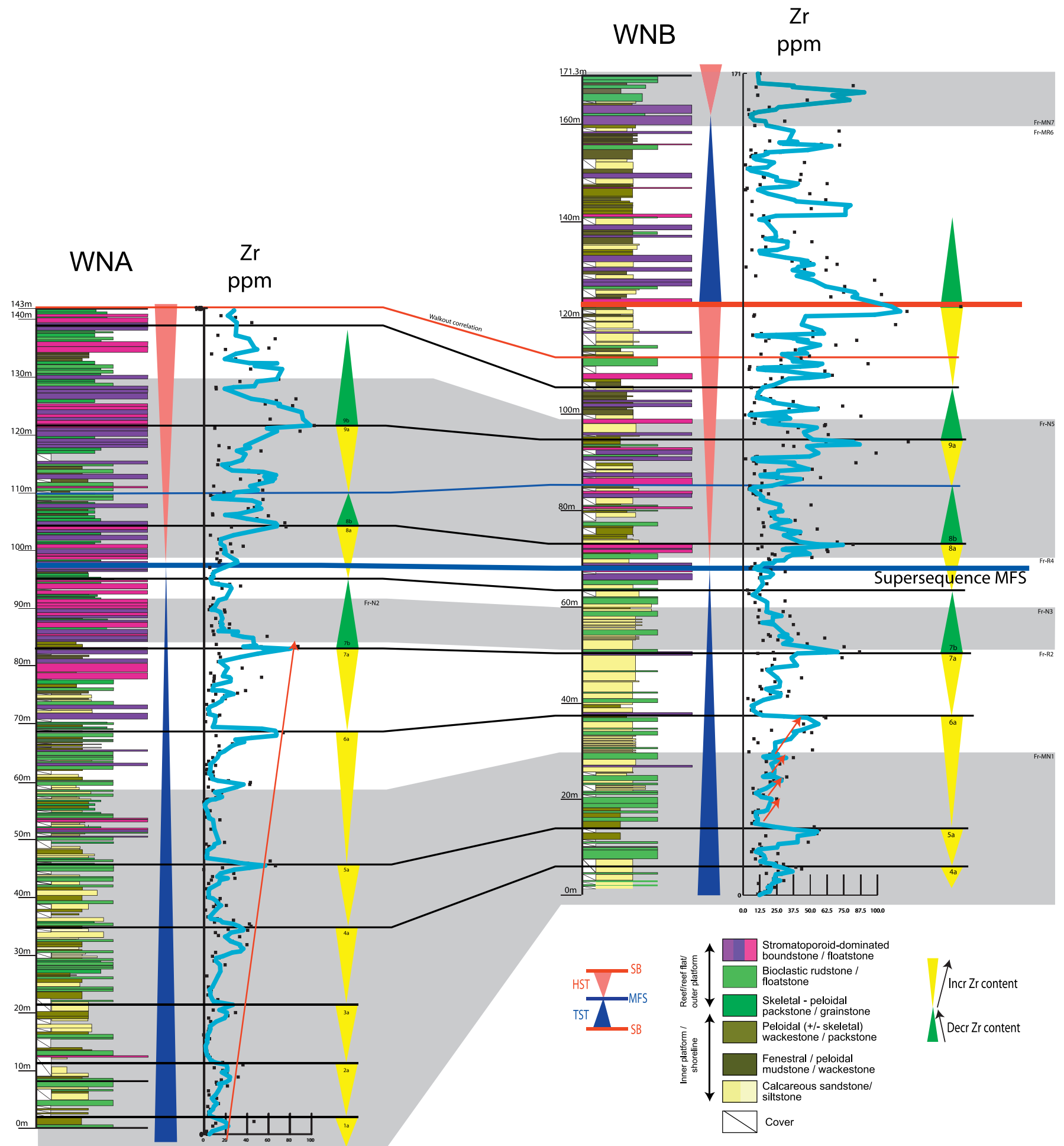

FIG. 8. - Correlation of WNA and WNB using changes in $\mathrm{Zr}$ concentrations. Black squares represent the concentration of $\mathrm{Zr}$ in each sample analyzed, and the blue line is a moving average of those values with $n=3$. The up-section trends in $Z r$ values are depicted in a manner similar to the way stacking patterns are displayed; upward-increasing $\mathrm{Zr}$ trends are displayed with a yellow triangle widening to the $\mathrm{Zr}$ maximum, and upward-decreasing $\mathrm{Zr}$ trends are displayed by a green triangle narrowing to the apex at the $\mathrm{Zr}$ minimum. The upward-increasing cycles are labeled 1a, 2a, etc., with 1a being the oldest. The oldest upward-decreasing trend sits on top of $7 \mathrm{a}$ and is therefore labeled $7 \mathrm{~b}$. Carbonate cycle stacking patterns are displayed for WNB (from Fig. 24 in Playton et al. 2016). 
maximum (labeled 1a-7a in WNA) display an overall upward increase, suggesting a cyclicity that is larger than the scale of these two sections on the scale of hundreds of meters. Finer-scale repetitive rhythms of parasequence scale are definable in places of higher sample density (e.g., 6a in WNB on Fig. 8).

\section{DISCUSSION}

While control on $\mathrm{Zr}$ concentration is unequivocally the amount of zircon derived from the nearby large landmass, the reason zircon varies systematically and in a time-significant manner is not readily apparent. The multiscaled (meters, decimeters, and hundreds of meters), repetitive rhythmic stacking seen in the $\mathrm{Zr}$ chemical logs is reminiscent of variations in sediments controlled by base-level fluctuations, irrespective of the actual variable being analyzed. For example, one can compare the $\mathrm{Zr}$ stacking patterns to the sigmoids, sets of sigmoids, and cosets of sigmoids of Pomar and Ward (1994, 1995) and resultant rhythmic variation in magnetic susceptibility described by Davies et al. (2013) in the reef complexes of Mallorca. Numerous authors have used magnetic susceptibility as a proxy for terrestrial input and demonstrated a base-level control (Da Silva and Boulvain 2002, 2006; Racki et al. 2002; Hladil et al. 2003; Da Silva et al. 2009). However, if a base-level control was responsible for the $\mathrm{Zr}$ stacking patterns in WNA and WNB, they should be expected to show close correspondence with the carbonate facies cycle stacking patterns defined by Playton et al. (2016). While in some cases the tops of $\mathrm{Zr}$ cycles correspond to carbonate cycle tops (e.g., $\mathrm{Zr}$ cycles $5 \mathrm{a}$ and $6 \mathrm{a}$ on Fig. 8), there is no consistent correlation between the two types of cycles. Additionally, in places, $\mathrm{Zr}$ maxima correspond to the top of upward-shoaling cycles, whereas elsewhere, they are coincident with the top of upward-deepening cycles (Fig. 8). Therefore, potentially, the $\mathrm{Zr}$ cycles were not created solely in response to base-level fluctuations.

Although the individual $\mathrm{Zr}$ cycles do not always correspond to carbonate cycles, the change from sawtooth $\mathrm{Zr}$ chemical logs to more symmetrical $\mathrm{Zr}$ chemical $\operatorname{logs}$ occurs in association with the interpreted supersequence MFS (Fig. 8) in WNA and WNB (Playton et al. 2016). One potential explanation for this change in $\mathrm{Zr}$ stacking patterns in association with the supersequence MFS is an increase in biohermal/reef-flat facies at the supersequence MFS in the two sections. Biohermal facies are highly productive, and with increased accommodation associated with the MFS, increasing carbonate production in a reef-flat setting would dilute clastic content, assuming relatively constant clastic supply.

In the depositional system studied, where there are clear, welldefined sandstone beds derived from a nearby landmass, it is reasonable to assume that zircon delivery to the shelf was riverine. If this assumption is correct, cycles 1 through 6 would indicate a repeated pattern of gradual increase in silt- to fine-sand-sized terrigenous content of the sediment over approximately $10 \mathrm{~m}$ of section, followed by a sharp decrease over about $50 \mathrm{~cm}$ of section (the resolution of sampling). Cycles 7 through 10, by contrast, indicate a repeated pattern of gradual increase in terrigenous content, followed by a gradual decrease in the terrigenous content. In this case, cycles 1 through 6 likely represent a prograding sequence, culminating in a maximum regressive surface (MRS), followed by rapid flooding and a MFS almost coincident with the MRS. Such stacking patterns would be inconsistent with the position in a long-term TST, because cycles within longer-term TSTs should have part of the flooding/rise preserved within them.

Another delivery mechanism for terrestrial material into carbonate settings is from windblown detritus. Examples where this is the primary delivery mechanism are from isolated carbonate platforms, such as those described by Davies et al. (2013). This is not the case for this part of the Lennard Shelf. In isolated platform settings, the amount of windblown detritus being delivered to the system is relatively constant and changes slowly in response to large global shifts in climate. In these cases, the terrigenous content of the deposited sediments is still linked to base-level fluctuations, where carbonate productivity and accommodation become the primary control; low carbonate productivity and low accommodation result in high terrigenous content, whereas high productivity and high accommodation dilute the windblown detritus (Da Silva et al. 2012). Assuming this mechanism, the $\mathrm{Zr}$ stacking patterns in cycles 1 through 6 would start with high accommodation and reduce to a minimum at the top of a cycle, before a rapid increase in accommodation. Therefore, a windblown delivery mechanism means the transgressive-regressive patterns suggested by the $\mathrm{Zr}$ concentrations are again inconsistent with the move toward a supersequence TST, where overall deepening and preservation of both prograding and retrograding parts of cycles would be expected. Furthermore, the rapid fluctuations of the $\mathrm{Zr}$ concentrations suggest that long-term climatic fluctuations are unlikely to have been the driving factor, and the coarser quartz fraction is too large for windblown processes.

Reworking of the clastic component, postdelivery, will influence the distribution of sediments on the shelf. The narrow shelf would have been prone to current sweeping and longshore drift processes, and the complex reentrant and promontory paleogeography of the shelf (Playford et al. 2009) would have caused complexity in currents, with resultant highly localized sediment dispersal patterns. A mixture of primary delivery signal and reworked signal in the clastic component potentially explains why, in places, $\mathrm{Zr}$ stacking patterns match carbonate cycle stacking patterns, but in other places, they do not.

Siliciclastic detritus is recorded throughout the shelf deposits, and beyond into other depositional settings of the shelf complex, intricately commingled with the carbonates and also forming discrete sandstone beds (Playton et al. 2016). The sandstone beds recorded in the back reef environment are not contiguous on the scale of this study and do not lend themselves to parasequence set interpretation because of their discontinuous character. This suggests that the terrestrial component, in this case, in the form of sandstone beds, was not reacting exclusively to base level. The ubiquitous presence of siliciclastic material in the platform-top setting was due to the constant proximity of the shoreline, which in turn was due to the narrowness of the carbonate platform in this area. This close proximity and constant supply of terrestrial detritus may be the reasons that terrestrial content fluctuations do not follow a classic carbonatesiliciclastic model with reciprocal sedimentation (Wilson 1967, Meissner 1972).

The detailed relationship between siliciclastic distribution and carbonate facies on the Lennard Shelf is outside the scope of this stratigraphic paper, but it warrants further investigation, both on the local scale as seen in the WNA and WNB sections, as well as further afield using other sections in the $\mathrm{CBCP}$.

\section{CONCLUSIONS}

This paper demonstrates that with paleomagnetic and ground truthing stratigraphic control on stratigraphy, high-resolution chronostratigraphic correlation between the two study sections can be achieved using cyclical changes in $\mathrm{Zr}$ concentrations. While no rigorously tested hypothesis for the controls on the $\mathrm{Zr}$ cycles can be put forward with the current data sets, it is apparent that the change in shape of cycles is coincident with the supersequence MFS and may therefore be a regionally significant feature. The peaks and troughs, however, likely only afford a local correlation feature.

Published approaches of chemostratigraphic siliciclastic workers in the mixed carbonate-siliciclastic sequences of the WNA and WNB sections do not provide meaningful results in this area. No clear stepped changes in elemental concentrations or element ratio values 
that relate to changes in provenance or paleoclimate can be identified in the sampled sections. Variable dolomitization prevents the use of trace element data for definition of paleoredox-based changes. Therefore, it is impossible to identify and correlate isochemical intervals; i.e., the chemostratigraphic packages or chemozones used by siliciclastic workers. However, with the stratigraphic constraints afforded by the paleomagnetism and ground truthing correlation, it is demonstrated here that the $\mathrm{Zr}$ stacking pattern approach does provide chronostratigraphically meaningful correlations.

The work in this paper is based on two closely spaced sections of limited stratigraphic extent from a platform top in the Canning Basin, an attached carbonate platform. However, the approach described can be applied to any sequence, irrespective of stratigraphic extent or age, depositional setting, or geological basin, including detached carbonate platforms, where airborne dust provides the terrigenous-related elemental signatures. Furthermore, the approach is applicable to subsurface settings where core and cuttings samples are available, thereby potentially providing a stratigraphic tool for the petroleum industry.

\section{ACKNOWLEDGMENTS}

We especially thank the Aboriginal tribes of the Bunaba and Gooniyandi (Kuniandi) people, who allowed us to conduct this research on their sacred lands. Thanks go to Paul Montgomery and Peter Cawood for the integrated chronostratigraphic vision, and to Phil Playford for introduction to the outcrop belt. Funding was supplied by the Australian Research Council Linkage Program (gran LP0883812), ARC-QEII Grant Program, ARC-DORA-3 Gran Program, Minerals Research Institute of Western Australia (MERIWA), Western Australian Energy Research Alliance (WAERA), Commonwealth Scientific and Industrial Research Organization (CSIRO), Buru, Chevron Australian Business Unit, Chevron Energy Technology Company, the University of Greenwich, and Chemostrat, Ltd. Field support and safety were provided by Wundargoodie Aboriginal Safaris (Colin and Maria Morgan and family and crew), the Geological Survey of Western Australia, Chevron Australian Business Unit, and Steve Meyer, Sean O'Connell, and Bill Robinson of Chevron. Thanks go to Windjana Gorge National Park, Napier Downs, the Mimbi Community, Mount Pierre Station, Fossil Downs Station, Brooking Downs Station, the Pillara Mine, and the Cadjebut Mine for field area access and resources. Thanks also go to $\mathrm{R}$. Addenbrooke, H. Allen, A. Duffy, G. Beacher, M. Diamond, M. Ducea, K. Grice, J. Hansma, K. Hillbun, T. Holland, J. Hsieh, D. Katz, J. Klemm, L. Lanci, K. Liebe, E. Maslen, L. McEvoy, F. Pardini, S. Pisarevsky, T. Raub, B. Roelofs, S. Shoepfer, U. Singh, S. Slotznick, S. Tulipani, M. Thorp, K. Trinajstic, T. Tobin, A. Vonk, F. Wellmann, P. Ward, and K. Williford for field assistance and project-related contributions beyond the scope of this paper. Roger Hocking and Peter Haines publish with the permission of the executive director of the Geological Survey of Western Australia. The Chemostrat authors would like to thank Chemostrat for allowing them time to publish this work. The authors are also grateful to the two referees, both of whom made invaluable suggestions that improved the publication.

\section{REFERENCES}

Algeo TJ, Schwark L, Hower JC. 2004. High-resolution geochemistry and sequence stratigraphy of the Hushpuckney Shale (Swope Formation, eastern Kansas): Implications for climato-environmental dynamics of the Late Pennsylvanian Midcontinent Seaway. Chemical Geology 206:259-288.

Armstrong-Altrin JS, Lee YI, Verma SP, Ramasamy S. 2004. Geochemistry of sandstones from the Upper Miocene Kudankulam Formation, southern India; implications for provenance, weathering and tectonic setting. Journal of Sedimentary Research 74:285-297.
Callonnec L, Renard M, De Rafélis M, Minoletti F, Beltran C, Du Chêne RJ 2014. Evolution of the trace element contents ( $\mathrm{Sr}$ and $\mathrm{Mn}$ ) of hemipelagic carbonates from the Zumaia Paleocene section (Gipuzkoa, Spain) Implications for the knowledge of seawater chemistry during the Selandian. Bulletin of the Geological Society of France 185:413-438

Coimbra R, Immenhauser A, Olóriz F, Rodríguez-Galiano V, Chica-Olmo M. 2015. New insights into geochemical behaviour in ancient marine carbonates (Upper Jurassic Ammonitico Rosso): Novel proxies for interpreting sea-level dynamics and palaeoceanography. Sedimentology 62:266-302.

Craigie NW. 2015. Applications of chemostratigraphy in Cretaceous sediments encountered in the North Central Rub' al-Khali Basin, Saudi Arabia. Journal of African Earth Sciences 104:27-42.

Da Silva AC, Boulvain F. 2002. Sedimentology, magnetic susceptibility and isotopes of a Middle Frasnian carbonate platform: Tailfer section, Belgium. Facies 46:89-102.

Da Silva AC, Boulvain F. 2006. Upper Devonian carbonate platform correlations and sea level variations recorded in magnetic susceptibility. Palaeogeography, Palaeoclimatology, Palaeoecology 240:373-388.

Da Silva AC, Dekkers MJ, Mabille C, Boulvain F. 2012. Magnetic susceptibility and its relationship with palaeoenvironments, diagenesis and remagnetisation: Examples from the Devonian carbonates of Belgium. Studia Geophysica et Geodaetica 56:677-704.

Da Silva AC, Potma K, Weissenberger JAW, Whalen MT, Humblet CM, Boulvain F. 2009. Magnetic susceptibility evolution and sedimentary environments on carbonate platform sediments and atolls, comparison of the Frasnian from Belgium and Alberta, Canada. Sedimentary Geology 214:3-18.

Davies EJ, Ratcliffe KT, Montgomery P, Pomar L, Ellwood BB, Wray DS 2013. Magnetic susceptibility $(\chi)$ stratigraphy and chemostratigraphy applied to an isolated carbonate platform reef complex; Llucmajor Platform, Mallorca. In Verwer K, Playton TE, Harris PM (Editors). Deposits, Architecture, and Controls of Carbonate Margin, Slope and Basinal Settings, Special Publication 105: SEPM (Society for Sedimentary Geology), Tulsa, Oklahoma. p. 142-156.

Davies EJ, Ratcliffe KT, Montgomery P, Pomar L, Ellwood BB, Wray DS 2014. A multi-facetted approach to stratigraphy: One that is applicable to the oil and gas industry. In Rocha R, Pais J, Kullberg JC, Finney S (Editors). Strati 2013, First International Congress on Stratigraphy at the Cutting Edge of Stratigraphy, Springer Geology: Springer International Publishing, Cham, Switzerland. p. 895-899.

Ehrenberg S, Siring E. 1992. Use of bulk chemical analysis in stratigraphic correlation of sandstones: An example from the Statfjord field, Norwegian continental shelf. Journal of Sedimentary Petrology 62:318-330.

Ellwood BB, Tomkin JH, Ratcliffe KT, Wright AM, Kafafy AM. 2008. Magnetic susceptibility and geochemistry for the Cenomanian/Turonian boundary GSSP with correlation to time equivalent core. Palaeogeography, Palaeoclimatology, Palaeoecology 251:1-22.

Ellwood BB, Wang W-H, Tomkin JH, Ratcliffe KT, El Hassani A, Wright AM. 2013. Testing high resolution magnetic susceptibility and gamma radiation methods in the Cenomanian-Turonian (Upper Cretaceous) GSSP and nearby coeval section. Palaeogeography, Palaeoclimatology, Palaeoecology 378:75-90.

George AD, Trinajstic KM, Chow N. 2009. Frasnian reef evolution and palaeogeography, SE Lennard Shelf, Canning Basin, Australia. In Königshof $\mathrm{P}$ (Editor). Devonian Change: Case Studies in Palaeogeography and Palaeoecology, Special Publication 314: Geological Society, London. p. 73 107

Gradstein FM, Ogg JG, Schmitz M, Ogg G. 2012. The Geologic Time Scale 2012: Elsevier, Amsterdam. 1254 p.

Hansma J, Tohver E, Yan M, Trinajstic K, Roelofs B, Peek S, Slotznick SP, Kirschvink J, Playton TE, Haines PW, Hocking RM. 2015. Late Devonian carbonate magnetostratigraphy from the Oscar and Horse Spring Ranges, Lennard Shelf, Canning Basin, Western Australia. Earth and Planetary Science Letters 409:232-242.

Hildred GV, Ratcliffe KT, Wright AM, Zaitlin BA, Wray DS. 2010 Chemostratigraphic applications to low-accommodation fluvial incisedvalley settings; an example from the Lower Mannville Formation of Alberta, Canada. Journal of Sedimentary Research 80:1032-1045. 
Hillbun K, Playton TE, Tohver E, Ratcliffe K, Trinajstic K, Roelofs B, Caulfield-Kerney S, Wray D, Haines P, Hocking R, Katz D, Montgomery P, Ward P. 2015. Upper Kellwasser carbon isotope excursion pre-dates the F-F boundary in the Upper Devonian Lennard Shelf carbonate system, Canning Basin, Western Australia. Palaeogeography, Palaeoclimatology, Palaeoecology 438:180-190.

Hladil J, Bosak P, Slavik L, Carew JL, Mylroie JE, Gersl M. 2003. Early diagenetic origin and persistence of gamma-ray and magnetosusceptibility patterns in platform carbonates: Comparison of Devonian and Quaternary sections. Physics and Chemistry of the Earth 28:719-727.

Hubert JF. 1962. A zircon-tourmaline-rutile maturity index and the interdependence of the composition of heavy mineral assemblages with the gross composition and texture of sandstones. Journal of Sedimentary Petrology 32:440-450.

Jarvis I, Jarvis KE. 1995. Plasma spectrometry in earth sciences: Techniques, applications and future trends. Chemical Geology 95:1-33.

Jarvis I, Murphy AM, Gale AS. 2001. Geochemistry of pelagic and hemipelagic carbonates: Criteria for identifying systems tracts and sea-level change. Journal of the Geological Society of London 158:685-696.

Klapper G. 2007. Frasnian (Upper Devonian) conodont succession at Horse Spring and correlative sections, Canning Basin, Western Australia. Journal of Paleontology 81:513-537.

Lowey GW. 2015. Element/aluminum ratios in chemostratigraphy: A dubious normalisation resulting in spurious correlations. Canadian Society of Petroleum Geologists Geoconvention Calgary 4-8 May 2015, 4 p.

Mabrouk A, Jarvis I, Belayouni H, Murphy A, Moody RTJ. 2007. Sequence stratigraphy, sea level change and palaeoenvironments via chemostratigraphy: Regional to global correlations. American Association of Petroleum Geologists Search and Discovery, article \#40244. Accessed June 30, 2007.

Meissner FG. 1972. Cyclic sedimentation in Middle Permian strata of the Permian Basin. In Elam JG, Chuber S (Editors). Cyclic Sedimentation in the Permian Basin, Publication 72-60: West Texas Geological Society, Midland, Texas. p. 203-232.

Montgomery P, Ratcliffe KT, Wray DS, Bachtel S, Wright M, McCarty D, Derkowski A, Archuleta B, Toomey N, Dull D, Meddaugh W, Urbat M. 2011. Application of whole rock inorganic geochemistry to stratigraphic understanding of mixed carbonate evaporite reservoirs, an example from the first Eocene of the Wafra Field, PZ. In Proceedings of the American Association of Petroleum Geologists Annual Meeting; April 10-13, 2011; Houston, Texas. American Association of Petroleum Geologists, Tulsa, Oklahoma. Search and Discovery article \#90124.

Morton AC, Hallsworth C. 2007. Stability of detrital heavy minerals during burial diagenesis. In Mange MA, Wright DT (Editors). Heavy Minerals in Use, Developments in Sedimentology 58: Elsevier, Amsterdam. p. 215-245.

Pearce TJ, Jarvis I. 1995. High-resolution chemostratigraphy of Quaternary distal turbidites: A case study of new methods for the analysis and correlation of barren sequences. In Dunay RE, Hailwood EA (Editors). NonBiostratigraphical Methods of Dating and Correlation, Special Publication 89: Geological Society, London. p. 107-143.

Pearce TJ, Martin JH, Cooper D, Wray DS. 2010. Chemostratigraphy of Upper Carboniferous (Pennsylvanian) sequences from the southern North Sea (United Kingdom). In Ratcliffe KT, Zaitlin BA (Editors). Modern Alternative Stratigraphic Techniques; Theory and Case Histories, Special Publication 94: SEPM (Society for Sedimentary Geology), Tulsa, Oklahoma. p. 109129.

Pearce TJ, Wray DS, Ratcliffe KT, Wright DK, Moscariello A. 2005. Chemostratigraphy of the Upper Carboniferous Schooner Formation, southern North Sea. In Collinson JD, Evans DJ, Holliday DW, Jones MS (Editors). Carboniferous Hydrocarbon Geology: The Southern North Sea and Surrounding Onshore Areas, Occasional Publications 7: Yorkshire Geological Society, Leicester, UK. p. 147-164.

Pe-Piper G, Triantafyllidis S, Piper DJW. 2008. Geochemical identification of clastic sediment provenance from known sources of similar geology: The Cretaceous Scotian Basin, Canada. Journal of Sedimentary Research 78:595-607.

Playford PE, Hocking RM, Cockbain AE. 2009. Devonian Reef Complexes of the Canning Basin, Western Australia: Geological Survey of Western Australia, East Perth, Australia. Bulletin 145. 444 p.
Playton TE, Kerans C. 2015a. Late Devonian carbonate margins and foreslopes of the Lennard Shelf, Canning Basin, Western Australia, Part A: Development during backstepping and the aggradation to-progradation transition. Journal of Sedimentary Research 85:1334-1361.

Playton TE, Kerans C. 2015b. Late Devonian carbonate margins and foreslopes of the Lennard Shelf, Canning Basin, Western Australia, Part B: Development during progradation and across the Frasnian-Famennian biotic crisis. Journal of Sedimentary Research 85:1362-1392.

Playton TE, Hocking RM, Tohver E, Hillbun K, Haines PW, Trinajstic K, Roelofs B, Katz DA, Kirschvink JL, Grice K, Montgomery P, Hansma J, Yan M, Pisarevsky S, Tulipani S, Ratcliffe KT, Caulfield-Kerney S, Wray DS. 2016. Integrated stratigraphic correlation of Upper Devonian platform-tobasin carbonates sequences, Lennard Shelf, Canning Basin, western Australia: advances in carbonate margin-to-slope sequence stratigraphy and stacking patterns. In Playton TE, Kerans C, Weissenberger J, (Editors). New Advances in Devonian Carbonates: Outcrop Analogs, Reservoirs, and Chronostratigraphy: Special Publication 107: SEPM (Society for Sedimentary Geology), Tulsa, Oklahoma. DOI: 10.2110/sepmsp.107.10

Pomar L, Ward WC. 1994. Response of late Miocene Mediterranean reef platform to high-frequency eustasy. Geology 22:131-134.

Pomar L, Ward WC. 1995. Sea-level changes, carbonate production and platform architecture: The Llucmajor Platform, Mallorca, Spain. In Haq BU (Editor). Sequence Stratigraphy and Depositional Response to Eustatic, Tectonic and Climate Forcing: Kluwer Academic Publishers, Berlin. p. 87112.

Racki G, Racka M, Matyja H, Devleeschouwer X. 2002. The Frasnian/ Famennian boundary interval in the South Polish-Moravian shelf basins: Integrated event stratigraphical approach. Palaeogeography, Palaeoclimatology, Palaeoecology 181:251-297.

Ramkumar M (Editor). 2015. Chemostratigraphy: Concepts, Techniques and Applications: Elsevier, Amsterdam. 538 p.

Ramkumar M, Stüben D, Berner Z. 2011. Barremian-Danian chemostratigraphic sequences of the Cauvery Basin, India: Implications on scales of stratigraphic correlation. Gondwana Research 19:291-309.

Ratcliffe KT, Hughes AD, Lawton DE, Wray DS, Bessa F, Pearce TJ, Martin J. 2006. A regional chemostratigraphically-defined correlation framework for the Late Triassic TAG-I in Blocks 402 and 405a, Algeria. Petroleum Geoscience 12:3-12.

Ratcliffe KT, Morton A, Ritcey D, Evenchick CE. 2007. Whole rock geochemistry and heavy mineral analysis as exploration tools in the Bowser and Sustut Basins, British Columbia, Canada. Journal of Canadian Petroleum Geology 55:320-336.

Ratcliffe KT, Wilson A, Payenberg T, Rittersbacher A, Hildred GV, Flint SS. 2015. Ground truthing chemostratigraphic correlations in fluvial systems. American Association of Petroleum Geologists Bulletin: 99:155-180.

Ratcliffe KT, Wright AM, Montgomery P, Palfrey A, Vonk A, Vermeulen J, Barrett M. 2010. Application of chemostratigraphy to the Mungaroo Formation, the Gorgon Field, offshore Northwest Australia. APPEA Journal 50th Anniversary Issue:371-388.

Ratcliffe KT, Wright AM, Spain D. 2012. Unconventional methods for unconventional plays: Using elemental data to understand shale resource plays. Petroleum Exploration Society of Australia News Resources Feb/ March:89-93.

Roelofs B, Playton TE, Barham M, Trinajstic K. 2015. Upper Devonian microvertebrates from the Canning Basin, Western Australia. Acta Geologica Polonica 65:69-101.

Rowe HD, Hughes N, Robinson K. 2012. The quantification and application of handheld energy-dispersive X-ray fluorescence (ED-XRF) in mudrock chemostratigraphy and geochemistry. Chemical Geology 324-325:122-131.

Sano JL, Ratcliffe KT, Spain DR. 2013. Chemostratigraphy of the Haynesville Shale. In Hammes U, Gale J (Editors). Geology of the Haynesville Gas Shale in East Texas and West Louisiana, U.S.A., Memoir 105: American Association of Petroleum Geologists, Tulsa, Oklahoma. p. 137-154.

Sarg JF, Markello JR, Weber LJ. 1999. The second-order cycle, carbonateplatform growth, and reservoir, source, and trap prediction. In Harris PM, Saller AH, Simo JA (Editors). Advances in Carbonate Sequence Stratigraphy: Application to Reservoirs, Outcrops and Models, Special 
Publication 63: SEPM (Society for Sedimentary Geology), Tulsa, Oklahoma. p. 11-34.

Śliwiński MG, Whalen MT, Meyer FJ, František M. 2012. Constraining clastic input controls on magnetic susceptibility and trace element anomalies during the Late Devonian punctata event in the Western Canada Sedimentary Basin. Terra Nova 24:301-309.

Soua M. 2010. Productivity and bottom water redox conditions at the Cenomanian-Turonian Oceanic Anoxic Event in the southern Tethyan margin, Tunisia. Revue Méditerranéenne de l'Environnement 4:653-664.

Stüben D, Kramar U, Harting M, Stinnedbeck W, Keller G. 2005. Highresolution geochemical record of Cretaceous-Tertiary boundary sections in Mexico: New constraints on the K/T and Chicxulub events. Geochimica et Cosmochimica Acta 69:2559-2579.

Tinnin B, Hildred G, Martinez N. 2013. Expanding the application of chemostratigraphy within Cretaceous mudrocks: Estimating total organic carbon and paleoredox facies using major, minor and trace element geochemistry. In Unconventional Resources Technology Conference (URTeC) August 12-14, 2013. Denver, Colorado. URTeC Control ID Number: 1579472.

Tribovillard N, Algeo T, Lyons TW, Riboulleau A. 2006. Trace metals as paleoredox and paleoproductivity proxies; an update. Chemical Geology 232:12-32.

Van der Weijden CH. 2002. Pitfalls of normalization of marine geochemical data using a common divisor. Marine Geology 184:167-187.

ver Straeten CA, Brett CE, Sageman BB. 2011. Mudrock sequence stratigraphy: A multi-proxy (sedimentological, paleobiological and geochemical) approach, Devonian Appalachian Basin. Palaeogeography, Palaeoclimatology, Palaeoecology 304:54-73.

Whalen MT, Day JE. 2010. Cross-basin variations in magnetic susceptibility influenced by changing sea level. Journal of Sedimentary Research 80:1109-1127.

Whalen MT, Śliwiński MG, Payne JH, Day JE, Chen D, Da Silva A-C. 2015. Chemostratigraphy and magnetic susceptibility of the Late Devonian Frasnian-Famennian transition in western Canada and southern China: Implications for carbon and nutrient cycling and mass extinction. In Da Silva A-C, Whalen MT, Hladil J, Chadimova L, Chen D, Spassov S, Boulvain F, Devleeschouwer X (Editors). Magnetic Susceptibility Application: A Window onto Ancient Environments and Climatic Variations, Special Publication 414: Geological Society, London. p. 37-72.

Wilson JL. 1967. Cyclic and reciprocal sedimentation in Virgilian strata of southern New Mexico. Geological Society of America Bulletin 78:805-818.

Wray DS, Gale AS. 2006. The palaeoenvironment and stratigraphy of Late Cretaceous chalks. Proceedings of the Geologists' Association 117:145-162.

Wright AM, Ratcliffe KT, Zaitlin BA, Wray DS. 2010. The application of chemostratigraphic techniques to distinguish compound incised valleys in low-accommodation incised-valley systems in a foreland-basin setting: An example from the Lower Cretaceous Mannville Group and Basal Colorado Sandstone (Colorado Group), Western Canadian Sedimentary Basin. In Ratcliffe KT, Zaitlin BA (Editors). Modern Alternative Stratigraphic Techniques: Theory and Case Histories, Special Publication 94: SEPM (Society for Sedimentary Geology), Tulsa, Oklahoma. p. 93-109. 